\title{
The Antibacterial Activities of Piper nigrum L. Against Mastitis Pathogens and its Antioxidant Activities
}

\author{
Gulten Okmen*, Mustafa Vurkun, Ali Arslan, Olcay Ceylan \\ Faculty of Science, Department of Biology, Mugla Sitki Kocman University, Kotekli Mugla 48000 TURKEY
}

\begin{abstract}
Objective / Purpose: Bacteria causes one of the most common types of chronic mastitis. The most common causative organisms of mastitis include: Staphylococci, Streptococci and coliforms. The scope of this work was to research the antibacterial effects of Piper nigrum extracts against mastitis pathogens, and its antioxidant capacity. Materials and Methods: In our study, 2 Staphylococcus aureus and 5 Coagulase Negative Staphylococcus were used for experiments. Additionally, Piper nigrum were collected from Mugla herbalists in Turkey. The plant extracts were tested by disc diffusion assay for antibacterial activity. The antioxidant activities of plant extracts were also determined by ABTS [2,2'-azino-bis(3-ethylbenzothiazoline-6-sulfonic acid)] method. Results: The methanol extract of plant showed maximum inhibition zone against 2 bacteria. MIC values of extracts are $6500 \mu \mathrm{g} / \mathrm{mL}$. The value found in ABTS method is highly effective (75.7\%). Discussion/Conclusion: As a result, the in vitro studies indicate that the extracts of Piper nigrum have significant antibacterial and antioxidant activities. In addition to, the plant extracts could be used in treating mastitis caused by the test bacteria.
\end{abstract}

Keywords: Piper, Mastitis, Staphylococcus, Antibacterial Activity, Antioxidant Activity.

\section{INTRODUCTION}

Mastitis is a complex disease, which is defined as inflammation of parenchyma of mammary glands and is characterized by physical, chemical and usually bacteriological changes in milk and pathological changes in glandular tissues. ${ }^{1}$ In this disease, the most common causative organisms are Staphylococci, Streptococci and coliforms. ${ }^{2}$ Coagulase-negative Staphylococci (CNS) have been considered to be minor mastitis pathogens, especially in comparison with major pathogens such as Staphylococcus aureus. The main reason for this is that mastitis caused by CNS is very mild, and usually remains subclinical. ${ }^{3}$

The continuous evolutions of bacterial resistance to currently available antibiotics are increasing problems. Drug-resistant bacteria create additional cases of illness, longer recuperation times and unnecessary deaths that necessitated the search for novel and effective antimicrobial compounds. ${ }^{4,5}$ This situation has forced scientists to search for new antimicrobial substances from various plants which are the good sources of novel antimicrobial chemotherapeutic agents. ${ }^{6,53,57}$ Because of the concern about the side effects of conventional medicine, the use of natural products as an alternative to conventional treatment in healing and treatment of various diseases has been on the rise in the last few decades. ${ }^{7,54}$

Black pepper or Piper nigrum is one of the most popular spice products in oriental countries (mostly in Southeast Asia). P. nigrum is a plant of the Piperaceae family, largely used as a flavouring agent in foods. Its characteristic aromatic odour is due to the volatile oils in the cells of the pericap. ${ }^{8}$ Piper nigrum $\mathrm{L}$. is used to treat asthma, chronic indigestion, colon toxins, obesity, sinus,
DOI: $10.5530 /$ ijper.51.3s.6

Correspondence:

Gülten Okmen,

Faculty of Science, Department of Biology, Mugla Sitki Kocman University, Kotekli Mugla 48000 TURKEY

Phone no:+90 2522111676

E-mail: gultenokmen@gmail. com

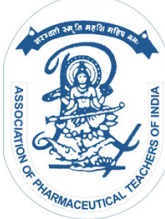

www.ijper.org 
congestion, fever,' intermittent fever, cold extremities, colic, gastric ailments and diarrhea. ${ }^{10}$ Black pepper has been shown to have antimicrobial activity. ${ }^{11,12}$ Both aqueous and ethanolic extracts of black pepper have been screened for antibacterial activity against a penicillin-G resistant strain of Staphylococcus aureus, ${ }^{13}$ Bacillus cereus and B. subtilis. ${ }^{14}$ Piperine ([1-[5-[1,3 benzodioxol-5-yl]1-oxo-2, 4, pentadienyl piperidine), a pungent alkaloid present in black pepper, enhances the bioavailability of various structurally and therapeutically diverse drugs. Larvicidal ${ }^{15}$ and anti-cancer ${ }^{16}$ activities of Piper nigrum Linn. have been reported.

Reactive oxygen species (ROS) have been implicated in degenerative diseases such as cancer, inflammation, atherosclerosis and aging as also in food deterioration. ${ }^{17-19}$ Restriction on the use of synthetic antioxidants due to their carcinogenic nature ${ }^{20}$ has lead to a growing interest in recent years in natural antioxidants of plant origin for application in food industry to combat food deterioration. Spices and herbs are recognized as sources of natural antioxidants and thus play an important role in the chemoprevention of diseases and aging. Many studies have reported that phenolic compounds in spices and herbs significantly contributed to their antioxidant and pharmaceutical properties. ${ }^{21-24,56}$ Kapoor et al. ${ }^{25}$ recently demonstrated that the protective effect of piperine is most likely due to its antioxidant activity. Although a few reports on the antioxidant activity of cultivated $P$. nigrum are available in the literature. ${ }^{26-30}$

The aim of the investigation presented in this paper is to evaluate the antibacterial and antioxidant activities of various extracts of Piper nigrum on several mastitis pathogens, as there is a significant lack of information on such activities in literature.

\section{MATERIAL AND METHODS}

\section{Plant material}

Piper nigrum were obtained from the local herbal market from Mugla in 2016. Taxonomical identification of plant was performed by Dr. Olcay Ceylan from the University of Mugla Sitk1 Kocman, Turkey. In the identification of this spice was used the Flora of Turkey (Herb no: MUH 1045). ${ }^{31}$

The Piper fruits were washed 3 times with running water and sterile distilled water. Then the spice material was air-dried. The fruits were powdered in a laboratory blender. All samples were stocked at room temperature, and they were stored at $4^{\circ} \mathrm{C}$ until required for analysis.

\section{Preparation of extracts}

The air dried and powdered fruits of the spice (50 g) were extracted with solvents using the Soxhlet. In this study, methanol, ethanol and ethyl acetate were used as solvent. After solvents have been evaporate, extracts $(250 \mathrm{mg} / \mathrm{mL})$ were kept in small sterile opac bottles under refrigerated conditions until used.

\section{Microorganisms and cultivation}

The bacteria obtained from previous studies by Dr. Zafer Cantekin, University of Mustafa Kemal (Project number: 1101 M 0103; Ethics council number: 2010 / 02- 30: 12). Seven bacteria were used in these studies. Two of them were $S$. aureus, and five of them were Coagulase- Negative Staphylococci (CNS). The bacteria were grown in Mueller- Hinton Broth for $24 \mathrm{~h}$ at $37^{\circ} \mathrm{C}$ (MHB; Merck). The bacteria were identified by conventional biochemical tests. ${ }^{32}$

\section{Determination of antibacterial activity}

In this study, the extracts were individually tested against mastitis bacteria. The antibacterial activities of extracts were determined by disc diffusion assay. The bacteria were grown on Mueller-Hinton agar plates (MHA, Merck) at $37^{\circ} \mathrm{C} . .^{33}$ The cultures of bacteria set to $0.5 \mathrm{Mc}$ Farland. Incubations of bacteria were at $37^{\circ} \mathrm{C}$ for $24 \mathrm{~h}$. The assessment of antibacterial activity was based on measurement of the diameter of the inhibition zones around the discs after $24 \mathrm{~h}$. Methanol, ethanol and ethyl acetate used as negative control. Ampicillin $(10 \mu \mathrm{g})$ antibiotic used as positive control. The extracts were impregnated to discs as $25 \mathrm{mg} / \mathrm{mL}$. All tests were performed in triplicate and the mean values were given.

\section{Determination of minimum inhibitory concentration (MIC)}

The other antibacterial activity test is MIC. The MIC value was taken as the lowest concentration that inhibits growth of bacteria after incubation. The broth dilution assay was made according to CLSI standards. ${ }^{34,35}$ The final concentrations of the extracts are 13000, 6500, $3250,1625,812.5 \mu \mathrm{g} / \mathrm{mL}$.

\section{Non- enzymatic antioxidant activity assay}

ABTS decolorization assay was used for non- enzymatic antioxidant activity experiments. ${ }^{36}$ Main stock liquid include $7 \mathrm{mM} \mathrm{ABTS} \bullet+\left[2,2^{\prime}\right.$-azino-bis(3-ethylbenzothiazoline-6-sulfonic acid)] solution and $2.45 \mathrm{mM}$ potassium persulfate solution. The absorbances were measured at $734 \mathrm{~nm}$ by spectrophotometry (Shimadzu UV-1201V, Japan). Trolox (6-hydroxy-2,5,7,8-tetramethychroman2-carboxylic acid; Sigma) was used as standard. Results of ABTS scavenging activities were given as mM Trolox equivalents (TE)/g dry mass. 


\section{RESULTS}

Results of antibacterial activities of different extracts are given in Table 1. The inhibition zones were recorded as $\mathrm{mm}$ for all the materials. The all of extracts of Piper nigrum were inhibited S. aureus-18, CNS-32, and CNS-36. The none of extracts of Piper nigrum were not inhibited S. aureus-17, CNS-32 and CNS-33. The highest inhibition zones were shown in $S$. aureus-18 and CNS-36, and its zone was $10 \mathrm{~mm}$. Ampicillin $(10 \mu \mathrm{g})$ used as positive control.

MIC values of Piper nigrum are shown Table 2. In this study, 2 bacteria showed lowest sensitivity to various extract of plant $(6500 \mu \mathrm{g} / \mathrm{mL})$. These bacteria are S. aureus-18 and CNS-36 (Table 2).

\begin{tabular}{|c|c|c|c|c|}
\hline \multicolumn{5}{|c|}{$\begin{array}{c}\text { Table 1: Antibacterial activities of Piper nigrum } \\
\text { various extracts against mastitis bacteria }\end{array}$} \\
\hline \multirow{2}{*}{ Bacteria } & \multicolumn{4}{|c|}{ Inhibition zone (mm) } \\
\cline { 2 - 5 } & Methanol & Ethanol & Ethyl acetate & A \\
\hline S.aureus- 17 & $(-)$ & $(-)$ & $(-)$ & 18 \\
\hline S.aureus- 18 & 10 & 8 & 8 & 12 \\
\hline CNS - 22 & $(-)$ & $(-)$ & $(-)$ & $(-)$ \\
\hline CNS - 32 & 8 & 8 & 8 & 10 \\
\hline CNS - 33 & $(-)$ & $(-)$ & $(-)$ & 8 \\
\hline CNS - 36 & 10 & 8 & 8 & $(-)$ \\
\hline CNS - 37 & $(-)$ & $(-)$ & 8 & $(-)$ \\
\hline
\end{tabular}

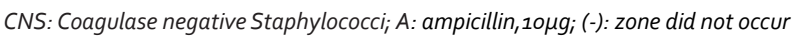

\begin{tabular}{|c|c|c|c|}
\hline \multirow{4}{*}{ Table 2: Minimum inhibitory concentrations of Piper } \\
nigrum various extracts $(\boldsymbol{\mu g} / \mathbf{m L})$
\end{tabular}

CNS: Coagulase negative Staphylococci (nt): Not tested; (-): inhibition did not occur

\begin{tabular}{|c|c|c|}
\hline Extracts & ABTS (\%) & TE \\
\hline Methanol & 8.6 & 1.5 \\
\hline Ethanol & 13.2 & 1.54 \\
\hline Ethyl acetate & 75.7 & 2.3 \\
\hline
\end{tabular}

TE: Trolox equivalent (mM/gDW); DW: dry weight
In our study, antioxidant capacities of extracts are very different. Two extracts of Piper nigrum have low radical scavenging ability. Table 3 shows these results. The ethyl acetate extract showed about $76 \%$ inhibition at $250 \mathrm{mg} / \mathrm{mL}$ concentration. Trolox equivalent value was $2.3 \mathrm{mM} / \mathrm{g}$ DW. Whereas, other extracts showed lower inhibition at $250 \mathrm{mg} / \mathrm{mL}$ concentration (Table 3).

\section{DISCUSSION}

The antimicrobial compounds from plants may inhibit bacteria by a different mechanism than the presently used antibiotics and may have clinical value in treatment of resistant microbial strains. Because of the side effects and bacteria resistance against the antibiotics, the scientist developed new drugs from natural sources such as plants, which have been extensively used as alternative treatment for disease. ${ }^{37,38}$ This study confirms that the fruits of Piper nigrum possess biological activities.

In the present study, the highest inhibition zone was determined on two bacteria (Table 1). Then one of extracts of Piper nigrum were not inhibited $S$. aureus-17, CNS-32 and CNS-33 (Table 1). Obasola, et al. ${ }^{39}$ and Kloos and Bannerman ${ }^{40}$ reported that CNS pathogens are resistive to most antibiotics. They have multi-resistance genes in plasmids which can be changes and they can spread among the different species covering also $S$. aureus. Parekh and Chanda ${ }^{41}$ reported that Piper nigrum was not inhibited S. epidermidis. The mode of action of antimicrobial agents also depends on the type of microorganisms and is mainly related to their cell wall structure and the outer membrane arrangement. The reports supported our results.

All of extracts of Piper nigrum were inhibited S. aureus-18, CNS-32, and CNS-36 (Table 1). Dorman and Deans ${ }^{11}$ reported that Piper nigrum inhibited $S$. aureus as $14.5 \mathrm{~mm}$. Reddy et al. ${ }^{42}$ reported that Piper nigrum suppressed $S$. aureus as $8-11 \mathrm{~mm}$. Nazia and Perween ${ }^{43}$ published that $P$. nigrum inhibited $S$. aureus as $23 \mathrm{~mm}$ inhibition zone. Shan et al. ${ }^{44}$ determined that $P$. nigrum repressed $S$. aureus as $4.6 \mathrm{~mm}$. Karsha and Lakshmi ${ }^{45}$ shown that Piper nigrum inhibited S. aureus as $14-20 \mathrm{~mm}$. Weerakkody et al. ${ }^{46}$ found that $P$. nigrum repressed S. aureus as 5-6 mm inhibition zone. Zarai et al. ${ }^{47}$ reported that inhibition zone of Piper nigrum shown 8-12 mm for $S$. aureus and 7-14 mm for $S$. epidermidis. The studies supported our results.

Sethi, et al. ${ }^{48}$ reported that minimum inhibitory concentration value (MIC) of Crocus sativus against $S$. aureus was found as $65 \mathrm{mg} / \mathrm{mL}$. Weerakkody et al..$^{46}$ found that MIC value of $P$. nigrum as $5 \mathrm{mg} / \mathrm{mL}$. Karsha and Lakshmi ${ }^{45}$ shown that MIC value of Piper nigrum found as $125 \mathrm{ppm}$. 
In this study, MIC value is $6500 \mu \mathrm{g} / \mathrm{mL}$, and these data are better than other studies (Table 2). Whereas, Zarai et al. ${ }^{47}$ reported that MIC values of Piper nigrum as 312.5 and $1250 \mu \mathrm{g} / \mathrm{mL}$. The differences in the antimicrobial activities with the reported one may be due to different geographical environment, age of the plant, different method followed for isolation of oil, cultivar type, seasonality etc. According to Aligiannis, et al. ${ }^{52}$ the extracts of Piper nigrum can be considered a weak inhibitor against mastitis pathogens.

Plants play a major role in providing the required antioxidants for the body. Although, traditionally, spices have been used in food preparations to improve flavour and taste. ${ }^{26}$ In our results, the ethyl acetate extract showed $76 \%$ inhibition at $250 \mathrm{mg} / \mathrm{mL}$ concentration. Whereas other extracts showed different inhibition at same concentration (Table 3). Zarai et al. ${ }^{47}$ reported that the ethanolic extract of Piper nigrum showed a high antioxidant activity $65.6 \%$ at final concentration of $50 \mu \mathrm{g} / \mathrm{mL}$. Shan $e t$ al. ${ }^{44}$ found that the antioxidant activity of fruit of black pepper as $4.6 \mathrm{mmol}$ TE/ $100 \mathrm{~g}$ DW. Ahmad et al.49 determined that callus of Piper nigrum have $40 \%$ antioxidant activity. Khalaf et al. ${ }^{50}$ reported that Piper nigrum inhibited DPPH. The inhibition rate is about $60 \%$. Singh et al..$^{27}$ told that the highest DPPH inhibition found $61 \%$ for ether extract. Gülçin ${ }^{21}$ reported that the highest DPPH inhibition of spice found $55 \%$ for ethanol extract. Our results are better than these studies. Furthermore, Fogden and Neuberger ${ }^{51-55}$ cited that the active constituents themselves are influenced by a wide range of factors: harvest season, preparation methods, plant species, and location including altitude and climate, and quality control.

\section{CONCLUSION}

Piper nigrum extracts tested in the study were determined to have potential antibacterial activities against $\mathrm{S}$. aureus and CNS pathogens isolated from subclinical cow mastitis. Our findings shown that Piper nigrum has biological activity. It would be very useful in the finding of novel antibacterial agents. Furthermore, plant extracts have great importance as antioxidant activities. Also, more researches involving more detailed studies to determine which components of spice extracts offer the best biological activity are advised.

\section{ACKNOWLEDGEMENT}

The authors thank Dr. Zafer Cantekin (Mustafa Kemal University, Turkey) for identification of mastitis pathogens.

\section{CONFLICT OF INTEREST}

None

\section{ABBREVIATION USED}

CLSI: Clinical and Laboratory Standards Institute MIC: Minimum inhibitory concentration; ABTS: 2,2'-azinobis(3-ethyl benzothiazoline-6-sulfonic acid); TE: Trolox equivalent; MHA: Mueller-Hinton Agar; MHB: Mueller-Hinton Agar; DPPH: 2,2-diphenyl-1-picrylhydrazyl; h: hour; $\mathrm{mg} / \mathrm{mL}$ : milligram/milliliters; ug/mL: microgram/milliliters; nm: nanometer; ${ }^{\circ} \mathrm{C}$ : Celsius degree; $\mathrm{mm}$ : millimeter.

\section{REFERENCES}

1. Radostits OM, Gay CC, Blood DC, Hinchcliff KW. Mastitis. In: Veterinary Medicine, 9th ed. London, W.B. Saunders Company Ltd. 2000;603-687.

2. McDonald JS. Bovine mastitis: Introductory remarks. J Dairy Sci. 1979;62(1):117-8.

3. Taponen S, Simojoki H, Haveri M, Larsen HD, Pyorala S. Clinical characteristics and persistence of bovine mastitis caused by different species of coagulase-negative Staphylococci identified with API or AFLP. Vet Microbiol. 2006;115(1):199-207.

4. Bokhari FM. Antifungal activity of some medicinal plants used in Jeddah, Saudi Arabia. Mycopath. 2009;7(1):51-7.

5. Aly MM, Bafeel S. Screening for antifungal activities of some medicinal plants used traditionally in Saudi Arabia. J Appl Anim Res. 2010;38(1):39-44.

6. Karaman İ, Şahin F, Güllüce M, Öğütçü H, Şengül M, Adıgüzel A. Antimicrobial activity of aqueous and methanol extracts of Juniperus oxycedrus L. J Ethnopharmacol. 2003;85(2):213-35.

7. Ansari MA, Ahmed S. A non-conventional herbal option for the management of seasonal allergic rhinitis. Pak J Pharmacol. 2006;23(4):31-5.

8. Murthy $\mathrm{CT}$, Bhattacharya S. Cryogenic grinding of black pepper. J Food Eng. 2008;85:18-28.

9. Ravindran PN. Black pepper: Piper nigrum. In: Ronald Haldman, editor. Medicinal and aromatic plants-industrial profiles. Australia: Harwood academic publisher; 2000.p.1-536.

10. Ao P, Hu S, and Zhao A. Essential oil analysis and trace element study of the roots of Piper nigrum L. J Zhongguo Zhong Yao Za Zhi. 1998;23(1):42-63.

11. Dorman HJD, Deans SG.Antimicrobial agents from plants: antibacterial activity of plant volatile oils. J Appl Microbiol. 2000;88(2):308-16.

12. Salie F, Eagles PFK, Leng HMJ. Preliminary antimicrobial screening of four South African Asteraceae species. J Ethnopharmacol. 1996;52(1):27-33.

13. Perez C, Anesini C. Antibacterial activity of alimentary plants against Staphylococcus aureus growth. Am J Chin Med. 1994;22(02):169-74.

14. Singh G, Marimuthu P, Murali HS, and Bawa AS. Antioxidative and antibacterial potentials of essential oils and extracts isolated from various spice materials. J Food Safety. 2005;25(2):130-45.

15. Chaudhry NM, Tariq P. Bactericidal activity of black pepper, bay leaf, aniseed and coriander against oral isolates. Pak J Pharm Sci. 2006;19(3):214-8.

16. Park IK, Lee SG, Shin SC,Park JD, Ahn YJ. Larvicidal activity of isobutylamides identified in Piper nigrum fruits against three mosquito species. J Agric Food Chem. 2002;50:1866-70

17. Ames BN, Shigrnaga MK, Hagen TM. Oxidants, antioxidants, and the degenerative diseases of aging Proceedings of the National Academy of Sciences; United States of America: 1993. 90:p.7915-22.

18. Halliwell B, Gutteridge JMC, Cross CE. Free radicals, antioxidants and human diseases: where are we now? J Lab Clin Med. 1992;119(6):598-620.

19. Larson RA. Naturally occurring antioxidants. Baco Raton: Lewis publishers; 1997. 
20. Lindenschmidt RC, Trika AF, Guard ME, Witschi HP. The effects of butylated hydroxytoluene on liver and colon tumor development in mice. Toxicol. 1986;38(2):151-60.

21. Gülçin I. The antioxidant and radical scavenging activities of black pepper (Piper nigrum) seeds. Int J Food Sci Nutr. 2005;56(7): 491-9.

22. Cai YZ, Luo Q, Sun M, Corke H. Antioxidant activity and phenolic compounds of 112 traditional Chinese medicinal plants associated with anticancer. Life Sci. 2004;74(17):2157-84.

23. Shan B, Cai $Y Z$, Sun M, Corke H. Antioxidant capacity of 26 spice extracts and characterization of their phenolic constituents. J Agr Food Chem. 2005;53(20):7749-59.

24. Wu CQ, Chen F, Wang X, Kim HJ, He GQ, Haley-ZitlinV, et al. Antioxidant constituents in feverfew (Tanacetum parthenium) extract and their chromatographic quantification. Food Chem. 2006;96(2):220-7.

25. Kapoor IPS, Singh B, Singh G, De Heluani CS, De Lampasona MP, Catalan CAN. Chemistry and in vitro antioxidant activity of volatile oil and oleoresins of Black pepper (Piper nigrum). J Agric Food Chem. 2009;57(12):5358-64.

26. Shobana S, Naidu KA. Antioxidant activity of selected Indian spices. PLEFA. 2000;62(2):107-10.

27. Singh R, Singh N, Saini BS, Rao HS. In vitro antioxidant activity of pet ether extract of black pepper. Indian J Pharmacol. 2008;40(4):147-51.

28. Topal U, Sasaki M, Goto M, Otles S. Chemical compositions and antioxidant properties of essential oils from nine species of Turkish plants obtained by supercriticial carbon dioxide extraction and steam distillation. Int J Food Sci Nutr. 2008;59(7-8):619-34.

29. Aziz N, Mehmood MH, Mandukhal SR, Bashir S, Raoof S, Gilani AH. Antihypertensive, antioxidant, antidyslipidemic and endothelial modulating activities of a polyherbal formulation (POL-10). Vascul Pharm. 2009;50(1):57-64.

30. Misharina TA, Terenina MB, Krikunova NI. Antioxidant properties of essential oils. Appl Biochem Microbiol. 2009;45:642-47.

31. Davis PH. Flora of Turkey and East Aegean Islands. Edinburgh: Edinburgh University Press; 1965. p.590.

32. Quinn PJ, Carter ME, Markey BK, Carter GR. Mycotoxins and mycotoxicoses. In: Clinical Veterinary Microbiology. London: Mosby-Year Book Europe Limited; Lynton House; 1994. p.648.

33. Bauer AW, Kirby WM, Sherris JC, Turck M. Antibiotic susceptibility testing by a standardized single disk method. Am J Clin Path. 1966;45(4):493-6.

34. CLSI (Clinical and Laboratory Standards Institute); National Committee for Clinical Laboratory Standards. Methods for dilution antimicrobial susceptibility test for bacteria that grow aerobically, 2003. Approved Standard M7-A $6^{\text {th }}$ edn. Wayne: Philadelphia, 2003

35. CLSI (Clinical and Laboratory Standards Institute); National Committee for Clinical Laboratory Standards. Performance standards for antimicrobial susceptibility testing, 2006. Informational Supplement M100-S1616th edn. Wayne: Philadelphia, 2006.

36. Re R, Pellegrini N, Protrggente A, Pannala A, Yang M, Rice-Evans C. Antioxidant activity applying an improved ABTS radical cation decolorization assay. Free Radical Bio Med. 1999;26(9):1231-37.

37. Sumitra C, Yogesh B. Extraction of active compounds of some medical plants. African J Biotechnol. 2010;9:3210-17.

38. Manoj M, Kailas C, Balaji V, Sajid N. Effect of plants extracts. Int J Pharm Tech Res. 2010;2:899-901.
39. Obasola EF, Cajethan OE, Abolade AO, Adeniyi AO. Comparative study of antibiotic resistance of Staphylococcus species isolated from clinical and environmental samples. AUJ Techn. 2010;13(3):165-9.

40. Kloos WE, Bannerman TL. Update on clinical significance of coagulasenegative Staphylococci. Clin Microb Rev. 1994;7(1):117-40.

41. Parekh J, Chanda S. Antibacterial and phytochemical studies on twelve species of Indian medicinal plants. Afr J Biomed Res. 2007;10(2):175-81.

42. Reddy VS, Srinivas PV, Praveen B, Kishore KH, Rajua BC, Murthy US, et al. Antibacterial constituents from the berries of Piper nigrum. Phytomedicine. 2004;11(7):697-700.

43. Nazia MAC,Perween T. Bactericidal activity of black pepper, bay leaf,aniseed and coriander against oral isolates. Pak J Pharm Sci. 2006;19(3):214-8.

44. Shan $B, C a i Y Z$, Brooks JD, Corke $H$. The in vitro antibacterial activity of dietary spice and medicinal herb extracts. Int J Food Microbiol. 2007;117(1):112-9.

45. Karsha PV, Lakshmi B. Antibacterial activity of black pepper (Piper nigrum Linn.) with special reference to its mode of action on bacteria. Indian J Nat Prod and Resour. 2010;1(2):213-5.

46. Weerakkody NS, Caffin N, Turner MS, Dykes GA. In vitro antimicrobial activity of less-utilized spice and herb extracts against selected food-borne bacteria. Food Control. 2010;21(10):1408-14.

47. Zarai Z, Boujelbene E, Salem NB, Gargouri Y, Sayari A. Antioxidant and antimicrobial activities of various solvent extracts, piperine and piperic acid from Piper nigrum. LWT - Food Sci Technol. 2013;50(2):634-41.

48. Sethi S, Dutta A, Gupta BL, Gupta S. Antimicrobial activity of spices against isolated food borne pathogen. Int J Pharm Pharm Sci. 2013;5(1):260-2.

49. Ahmad NH, Fazal BH, Abbasi M, Rashid T, Fatima MN. Efficient regeneration and antioxidant potential in regenerated tissues of Piper nigrum L. PCTOC. 2010;102(1):129-34.

50. Khalaf NA, Shakya AK, Al-Othman A, El-Agbar Z, Farah H. Antioxidant activity of some common plants. Turk J Biol. 2008;32(1):51-5.

51. Fogden E, Neuberger J. Alternative medicines and the liver. Liver Int. 2003;23(4):213-20.

52. Aligiannis N, Kalpoutzakis E, Mitaku S, Chinou IB. Composition and antimicrobial activity of the essential oils of two Origanum species. J Agric Food Chem. 2001;49:4168-70.

53. Mahendra P, Bisht S. Ferula asafoetida: Traditional uses and pharmacological activity. Phcog Rev. 2012;6(12):141-6.

54. Bawadi HA, Maghaydah SN, Tayyem RF, Tayyem RF. The postprandial hypoglycemic activity of fenugreek seed and seeds' extract in type 2 diabetics: A Pilot Study. Phcog Mag. 2009;5(18):134-8.

55. Çaliskan O, Gündüz K, Serçe S, Toplu C, Kamiloglu Ö, Sengül M, et al. Phytochemical characterization of several hawthorn (Crataegus spp.) species sampled from the Eastern Mediterranean region of Turkey. Phcog Mag. 2012;8(29):16-21.

56. Polat AA, Caliskan O, Serce S, Saracoglu O, Kaya C, Ozgen M. Determining total phenolic content and total antioxidant capacity of loquat cultivars grown in Hatay. Phcog Mag. 2010;6(21):5-8.

57. Calzada F, Juárez T, García-Hernández N, Valdes M, Ávila O, Mulia LY, Velázquez C. Antiprotozoal, antibacterial and antidiarrheal properties from the flowers of Chiranthodendron pentadactylon and isolated flavonoids. Phcog Mag. 2017;13(50):240-4. 
PICTORIAL ABSTRACT

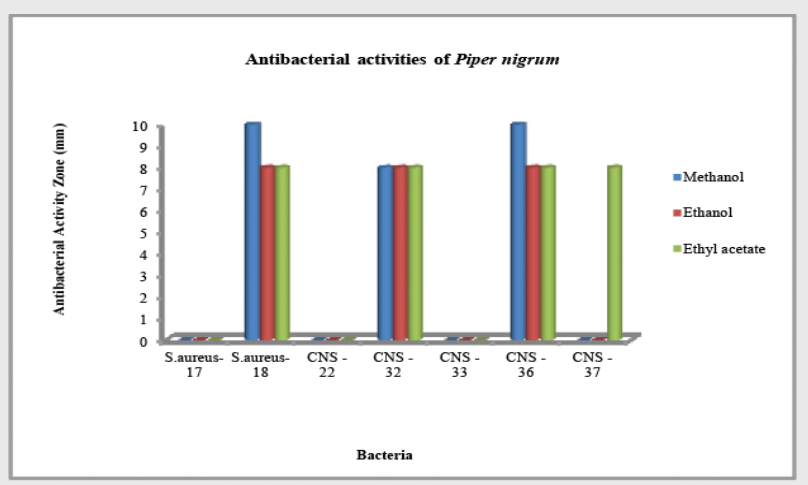

\section{SUMMARY}

- The highest antibacterial activity was determined from methanol extract for Staphylococcus aureus-17 and CNS-36. In this study, all of the bacteria were shown sensivity for $6500 \mu \mathrm{g} / \mathrm{mL}$ concentration. The highest antioxidant activity was shown at ethyl acetate extract. Our results suggest that Ribes nigrum has significant antibacterial and antioxidant activity and it could be very useful in the discovery of novel antibacterial and antioxidant agents of plant origin.

\section{About Authors}

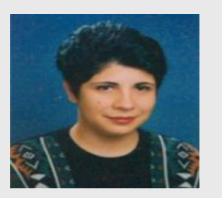

Assoc. Prof. D. Gülten Okmen: She works Mugla Sitki Kocman University in Biology Department. She is member of the European Association of Biotechnology and Biologists Association. She has a lot of scientific meetings and publications. She teaches a lot of curses at the bachelor and graduate degree. She done Ph. D degree at Ankara University, Department of Biology.She is working about Archaeal, Cyanobacterial and Microbial Biotechnology. She also worked as a potential reviewer for various national and international journals.

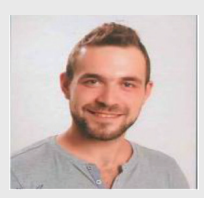

Msc. Mustafa Vurkun: He is MSc.student at Mugla Sitki Kocman University and works about Microbial Biotechnology. He works about Methicillin resistance Staphylococcus aureus (MRSA). $\mathrm{He}$ has a lot of scientific meetings and article. He is pursuining his MSc. at Mugla Sitki Kocman University.

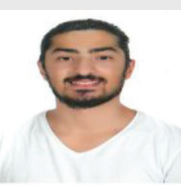

MSc. Ali Arslan: He is MSc.student in the scope of Microbial Biotechnology at Mugla Sitki Kocman University. He works about Archaea. He has a lot of scientific meetings and article. He is pursuining his MSc. at Mugla Sitki Kocman University.

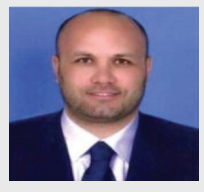

Ph.D Olcay Ceylan: He works Mugla Sitki Koçman University in Biology Departmant. He is working about systematic botanic. He has a lot of scientific meetings and article. He done Ph.D at Mugla Sitki Kocman University in Biology Departmant.

Cite this article: Okmen G, Vurkun M, Arslan A, Ceylan O. The Antibacterial Activities of Piper nigrum L. Against Mastitis Pathogens and its Antioxidant Activities. Indian $\mathrm{J}$ of Pharmaceutical Education and Research. 2017;51(3)Suppl:S170-75. 